\title{
Plant communities as a tool in temporary ponds conservation in SW Portugal
}

\author{
C. Pinto-Cruz $\cdot$ J. A. Molina $\cdot$ M. Barbour . \\ V. Silva $\cdot$ M. D. Espírito-Santo
}

Published online: 5 August 2009

(C) The Author(s) 2009. This article is published with open access at Springerlink.com

\begin{abstract}
Temporary ponds are seasonal wetlands annually subjected to extreme and unstable ecological conditions, neither truly aquatic nor truly terrestrial. This habitat and its flora have been poorly studied and documented because of the ephemeral character of the flora, the changeable annual weather that has a great effect on the small, herbaceous taxa and the declining abundance of temporary ponds. The objectives of this study are: (a) to define plant community diversity in terms of floristic composition
\end{abstract}

Guest editors: B. Oertli, R. Cereghino, A. Hull \& R. Miracle Pond Conservation: From Science to Practice. 3rd Conference of the European Pond Conservation Network, Valencia, Spain, 14-16 May 2008

C. Pinto-Cruz $(\square)$

Departamento de Biologia, ICAAM-Instituto de Ciências Agrárias e Ambientais Mediterrânicas, Universidade de Évora, Apartado 94, 7002-554 Évora, Portugal e-mail: ccruz@uevora.pt

\section{J. A. Molina}

Departamento de Biología Vegetal II, Universidad

Complutense de Madrid, E-28040 Madrid, Spain

M. Barbour

Department of Plant Sciences, University of California, Davis, CA 95616, USA

V. Silva · M. D. Espírito-Santo

Departamento de Protecção de Plantas e de Fitoecologia, CBAA-Centro de Botânica Aplicada à Agricultura, Instituto Superior de Agronomia, Tapada da Ajuda, 1349-017 Lisbon, Portugal of ephemeral wetlands in SW Portugal, (b) to identify temporary pond types according to their vegetation composition and (c) to identify those ponds that configure the European community priority habitat (3170* - Mediterranean temporary ponds).

Vegetation sampling was conducted in 29 ponds, identifying 168 species grouped among 15 plant communities. Soil texture, $\mathrm{pH}$, organic $\mathrm{C}$ and $\mathrm{N}$ content were measured, but only $\mathrm{N}$ and percent of clay appear to be related with the distribution of each community type. The results showed that ephemeral wetlands could be classified into four type: vernal pools, marshlands, deep ponds and disturbed wetlands. Vernal pools correspond to the Mediterranean temporary ponds $(3170 *)$, protected as priority habitat under the EU Habitats Directive. Submersed Isoetes species (Isoetes setaceum and Isoetes velatum) represents, together with Eryngium corniculatum, the indicator species for vernal pools. We identify also indicator plant communities of this priority habitat, namely I. setaceum and E. corniculatum-Baldellia ranunculoides plant communities. In this region, the conservation of temporary ponds has so far been compatible with traditional agricultural activities, but today these ponds are endangered by the intensification of agriculture and the loss of traditional land use practices and by the development of tourism.

Keywords SW Portugal - Temporary ponds · Ephemeral vegetation · Pond typology 


\section{Introduction}

The Mediterranean Basin has been recognised as a global biodiversity "hotspot" (Blondel \& Arronson, 1999). Temporary ponds are classified among the most biologically and biogeographically interesting ecosystems in the Mediterranean region (Grillas et al., 2004). Temporary ponds (vernal pools) are unusual habitats, neither truly aquatic nor truly terrestrial. They are seasonal wetlands with annually alternating phases of flooding and drying in shallow depressions. The water-holding capacity is, in some cases, related with the underlining impervious substrate (Keeley \& Zedler, 1998). Braun-Blanquet (1936) was among the first to point out the high biological value of temporary ponds, but new interest has grown among several ecologist in the Mediterranean region.

The ephemeral vegetation of temporary ponds is dominated mainly by annual and herbaceous perennials that appear during winter and spring months. The vegetation is diverse and is rich in annual hygrophytes, hemicryptophytes and geophytes (Brullo \& Minissale, 1998; Barbour et al., 2003; Deil, 2005). Species composition and the dynamics of plant communities in Mediterranean temporary ponds are affected by inter- and intra-annual climatic conditions (Rhazi et al., 2001; Espírito-Santo \& Arsénio, 2005). Studies on Portuguese vernal pools mainly remain at a descriptive level (Jansen \& Menezes de Sequeira, 1999; Pinto-Gomes et al., 1999; Rosselló-Graell et al., 2000; Espírito-Santo \& Arsénio, 2005; Rudner, 2005a, b).

Temporary ponds are extremely vulnerable habitats due to their small size, shallow depth of water, proximity to expanding urban areas and to intensive agriculture, industrialisation, development of tourism and their scattered and isolated distribution at a regional level. Temporary ponds have, for thousands of years, been compatible with and even favoured by traditional farming regimes, but modern agriculture obliterates them (Rhazi et al., 2001; Beja \& Alcazar, 2003). They are recognized by the Ramsar Convention on Wetlands and some are priority habitats under the Habitats Directive of the European Community (Natura 2000 code: $3170^{*}$ - Mediterranean temporary ponds).

Mediterranean temporary ponds are significant and highly sensitive ecosystems that should be studied more due to their vulnerability to human activities and climate changes (Stamati et al., 2008). We hypothesize that temporary pond types can be defined according to their plant community composition and that some communities or mixture of communities in a pond is related to their conservation status. The objectives of this study are: (a) to define plant community diversity in terms of floristic composition of ephemeral wetlands in SW Portugal, (b) to identify temporary pond types according to their vegetation composition and (c) to identify those ponds that configure the European community priority habitat (3170* - Mediterranean temporary ponds). It is important to define seasonal wetland typology to establish conservation priorities. The assessment of the conservation status can be used as a basis for management strategies.

\section{Materials and methods}

Study area

The study area is the coastal plain of southwest Portugal, which runs north-south for about $100 \mathrm{~km}$ long $x$ 5-15 km wide, ranging $50-150 \mathrm{~m}$ above sea level (Fig. 1). This area hosts a large number of seasonal wetlands as a consequence of climatic, edaphic and topographic characteristics. The approximate pond density in the studied area is 0.28 per $\mathrm{Km}^{2}$. Waters are soft to slightly hard, circum-neutral to slightly acidic and sometimes high in phosphates and nitrates (Beja \& Alcazar, 2003).

This coastal platform is carved in Palaeozoic schist and covered by sandstone types (sands, sandstone and conglomerates as described by Neto et al., 2007). The lithology of the territory includes siliceous materials and base-poor soils. According to local weather data (INMG, 1991), the climate is Mediterranean with an oceanic influence. From north to south, the mean annual precipitation declines from 614 to $456 \mathrm{~mm}$, falling mainly from October to March. Thus, aridity increases southwards. Winter and summer average temperatures are 11 and $20.5^{\circ} \mathrm{C}$, respectively.

This area is administered as the Natural Park, of southwest Alentejo and Vicentina Coast, a large stretch of the Portuguese coastline subject to special protection. Nevertheless, a high percentage of the ephemeral wetlands are privately owned. The 
Fig. 1 Location of the 29 sampled temporary ponds. Map layout created with Quantum GIS

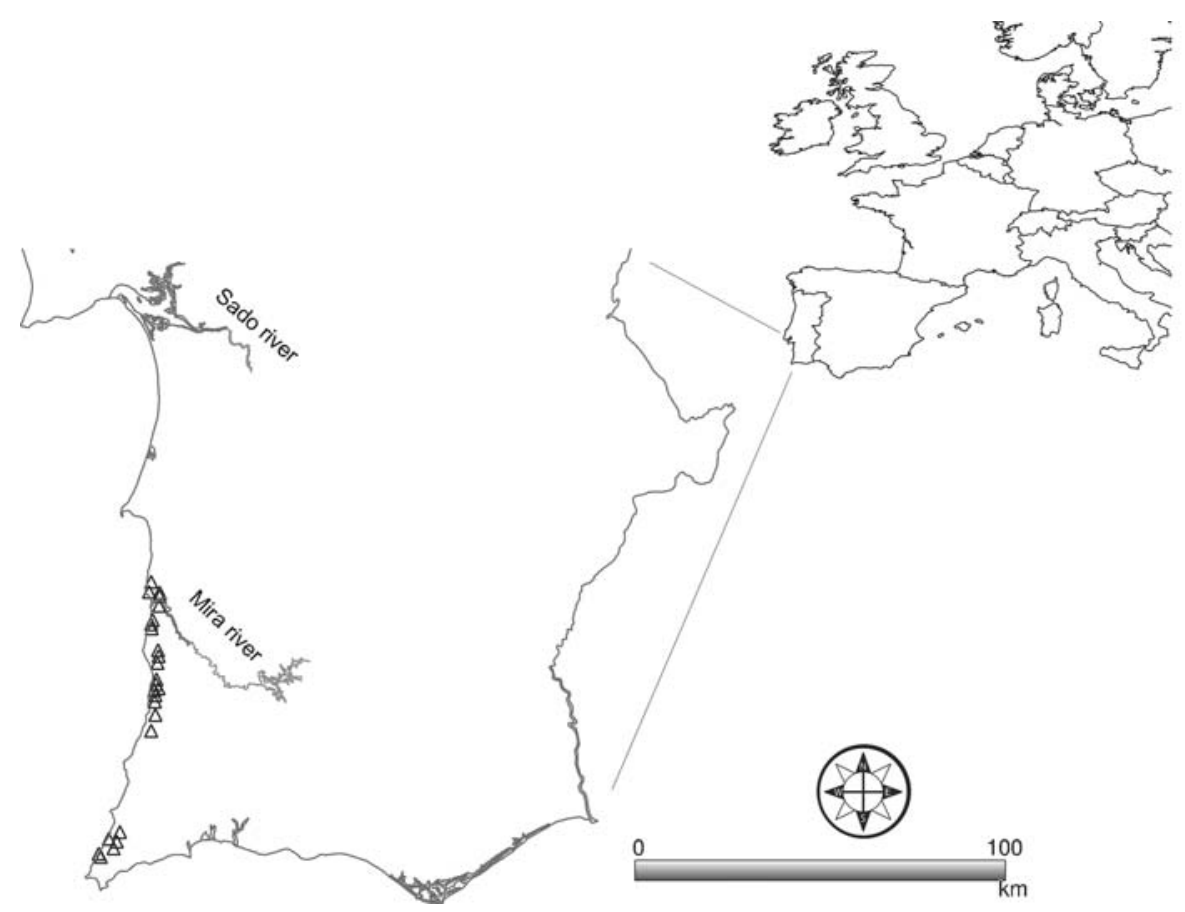

traditional land uses in the regions were extensive agriculture and livestock pastures in rotation. Presently, some 12,000 ha are administrated by a hydrological plan to further develop agricultural activities. In 2006 and 2007, fodder and maize occupied the largest areas, around 18-20\% each (ABM, 2007, 2008).

\section{Data collection}

The vegetation was sampled in a stratified random manner to obtain broadly representative data (Kent \& Coker, 1992). The stratification took into account lithology (sands and conglomerates) as well as the wetland's morphology (area 0.1-5 ha, depth 0.4$2 \mathrm{~m}$ ). Field sampling was carried out in 29 seasonal wetlands. The study period extended from late winter (February) to early summer (June) in 2006 and 2007. Ponds were visited twice a year. Plant communities were surveyed in visually homogenous $4 \mathrm{~m}^{2}$ quadrats, and each taxon's percent cover was recorded adapting Braun-Blanquet's (1964) method to allow conventional multivariate procedures (Podani, 2006). In each pond all physiognomically homogeneous patches of vegetation were sampled. Usually, three types, at different pond depths (margin, intermediate and deep parts), were present and each was sampled twice. Plant community types were named according to the syntaxonomical checklist of Rivas-Martínez et al. (2001, 2002a, b). Plant nomenclature follows Flora Iberica (Castroviejo et al., 1986-2008) and Nova Flora de Portugal (Franco, 1984; Franco \& Rocha Afonso, 1994-2003).

In each pond, soil surface samples were collected with a hand probe and mixed for chemical and physical analyses. Soil samples were air-dried and sieved at $2 \mathrm{~mm}$. Three fractions (sand, silt and clay) of soil texture were determined for each sample using the sedimentation method (Sedigraph 5100, Micrometrics Instrument Corporation). Standard soil analyses were carried out to determine the soil $\mathrm{pH}$ in a 1:2.5 soil-water suspension (glass electrode CRISON, Microph 2002), conductivity in a 1:5 suspension microprocessor conductivity meter LF 330 WTW and a standard conductivity cell Tetracon 325 , and organic carbon by dry combustion analysed by an SC-144DR (LECO Instruments). Determination of nitrogen content was made after the ISO 14891:2002 standard (ISO/IDF, 2002).

Data analysis

The data set includes 302 relevés and 168 species. The raw matrix was analysed with the software 
package SYN-TAX 5.0 (Podani, 2001) and plant community types were recognized with Hierarchical Cluster Analysis using the weighted-pair group method (WPGMA) and Chord Distance as a dissimilarity measure. Similarity Analysis (ANOSIM) with Bray-Curtis similarity measure (PRIMER, version 6) was used to test for significant differences in plant community composition. Indicator species analysis (Dufrêne \& Legendre, 1997) evaluated taxonomic consistency of plant communities by calculating species fidelity to each cluster, identifying species responsible for differences between plant groups (software PC-ORD 4).

Based on the relative abundance of plant communities in each pond, an incremental sum of squares, with standardized Euclidean distance, cluster analysis, was performed to group the ponds (SYN-TAX 5.0). Also, based on the relative abundance of plant communities, an initial detrended correspondence analysis (DCA) was carried out to determine the gradient lengths before deciding on the most appropriate method for analysis. Principal components analysis (PCA) was carried out to define pond groups using the program CANOCO 4.5. (ter Braak \& Šmilauer, 2002).

Multiple discriminant analysis (MDA) (Legendre \& Legendre, 1998) was used to determine the best set of variables that discriminate groups among the PCA clusters, based on several soil environmental variables: soil texture, $\mathrm{pH}$, conductivity, organic carbon and $\mathrm{N}$ content. In order to eliminate those variables that provided insignificant information $(P=0.01)$, a forward stepwise procedure was applied to each variable. For this last analysis SPSS-15.0 program package was used. Prior to analysis, all data were either $\log 10(x+1)$ (linear measurements) or arcsin [sqrt $(x)$ ] (percentages) transformed to improve normality.

\section{Results}

Plant community types

Ephemeral wetlands, taken as a group, are rich in species (168 taxa in our study) and in community types. Some 15 community types, putative associations or alliances, were identified by cluster analysis, using floristic information (Table 1). Significant differences $(P<0.01)$ from similarity analysis were observed for all communities. Indicator species analysis identified characteristics species for each community. The mean number of taxa per plant community (see Table 1) ranged from 5-6 in aquatic communities in wetland bottoms to $17-21$ in ephemeral grasslands in wetland margins.

Aquatic vegetation is represented by crowfoot (L-Ranunculus peltatus) and water-milfoil ( $\mathrm{N}-$ Myriophyllum alterniflorum) communities. Helophytic vegetation is constituted by low grasslands (E-Eleocharis palustris-Glyceria declinata), bulrushes (O-Bolboschoenus maritimus) and endemic rushes (F-Juncus emmanuelis) communities. Amphibious vernal pool vegetation includes Atlantic decumbentfloating vegetation (D-Eleogiton fluitans-Juncus heterophyllus communities), quillwort swards ( $C$ Juncus capitatus-Isoetes histrix communities, JIsoetes setaceum communities) and Mediterranean thistles (I-Eryngium corniculatum-Baldellia ranunculoides communities). Marshland communities are dominated by $H$-Agrostis castellana, together with $K$-Eleocharis multicaulis communities in the margins. Edge vegetation includes communities dominated by rushes (B-Juncus rugosus), perennial grasslands $(G-$ Phalaris coerulescens and $H-A$. castellana) and annual grasslands ( $M$-Chaetopogon fasciculatus communities) (Table 2).

\section{Habitats and Communities}

A previous numerical clustering allowed identifying three habitat groups and a subgroup namely: vernal pools (VP) within which deep ponds (L) can be identified as a subgroup, marshlands (M) and disturbed wetlands (D). The PCA ordination diagram (Fig. 2) also distinguished these units. Axis 1 separated the wetlands containing ephemeral temporary ponds' plant communities (e.g. I. setaceum communities, E. corniculatum-B. ranunculoides communities and $C$. fasciculatus communities) from the others. Deep ponds occurring in the far right side of the ordination diagram are defined by aquatic and bulrush communities such as $R$. peltatus communities, M. alterniflorum communities, and B. maritimus communities. In the left half part of the ordination diagram (axis 2), separated wetlands were characterised by typical marshland plant communities 


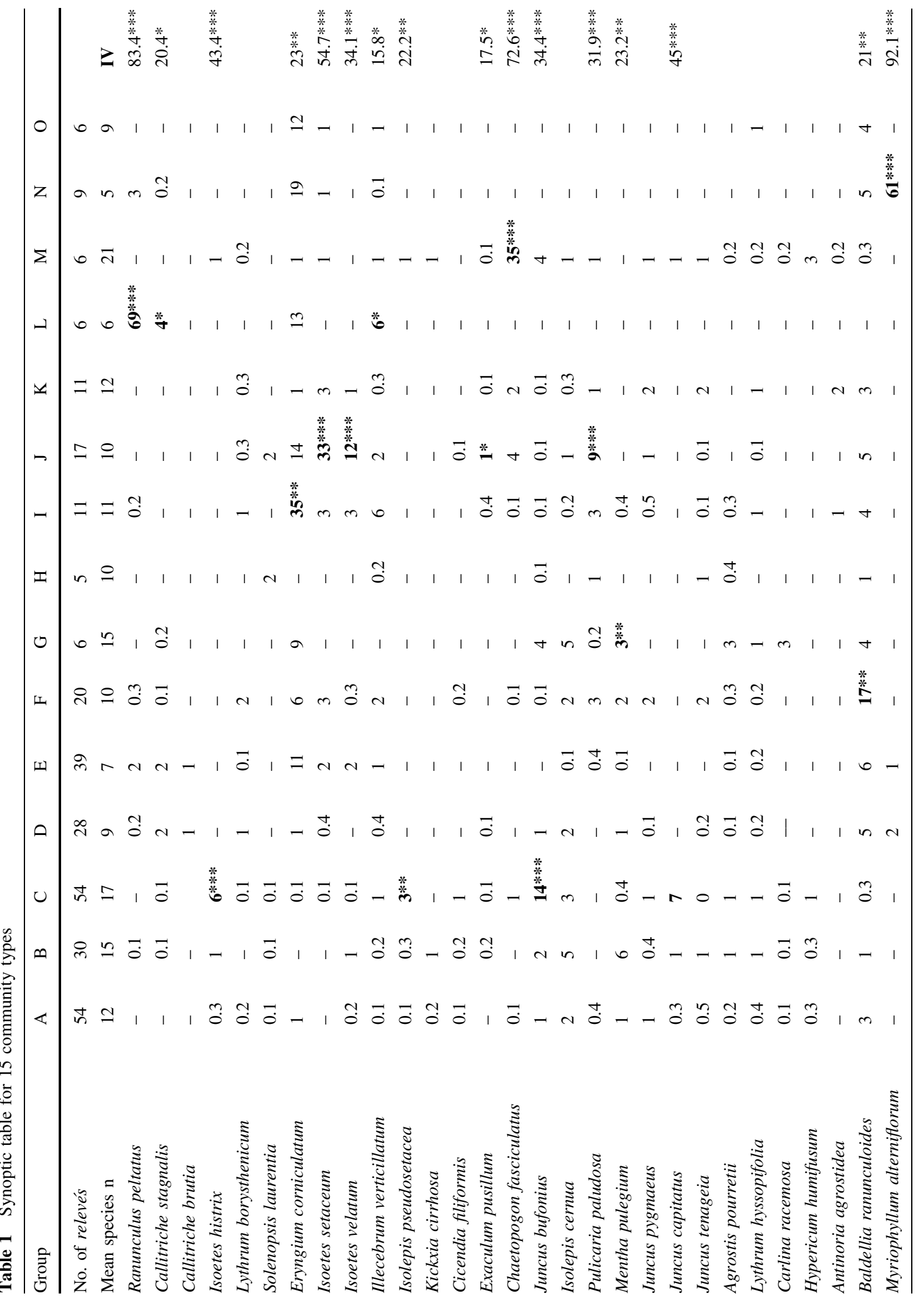




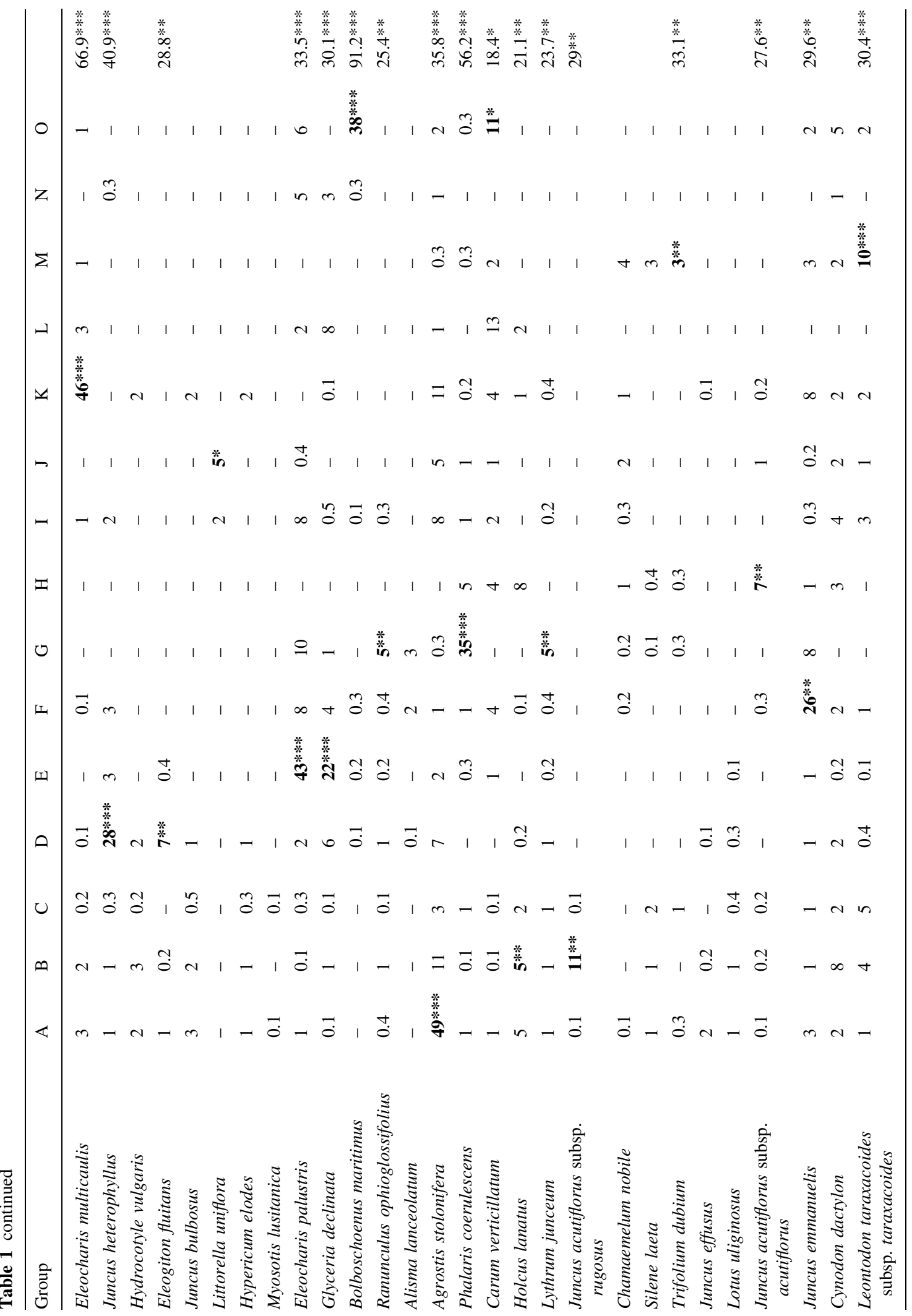


Hydrobiologia (2009) 634:11-24

17

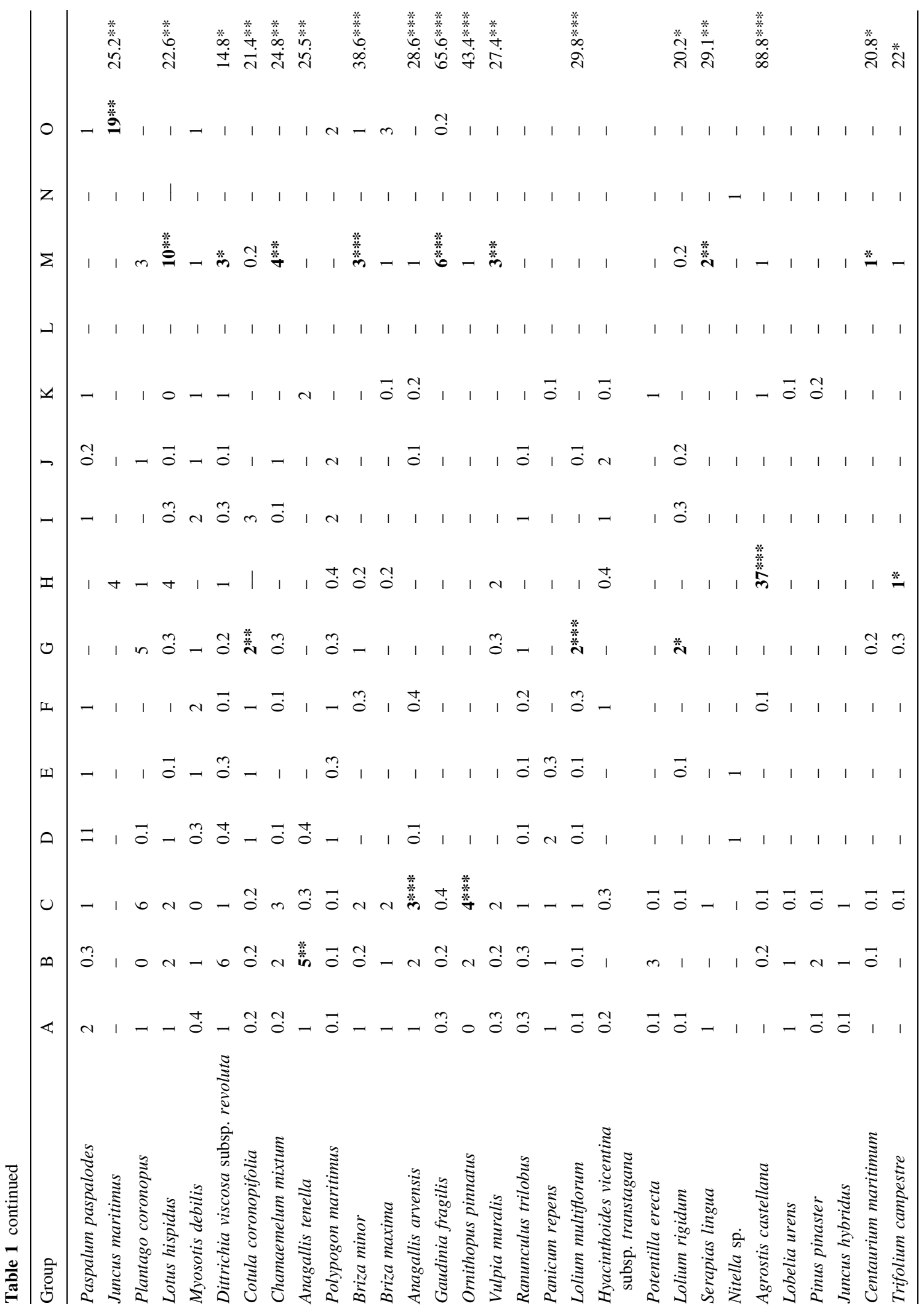

Springer 


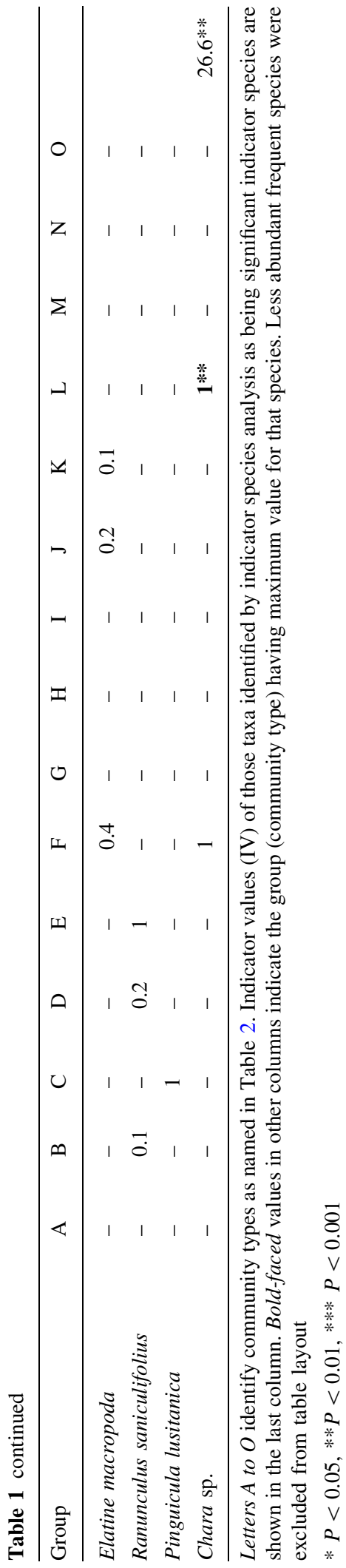

such as E. multicaulis communities and J. rugosus communities (lower left quadrant) from other wetlands poorly characterised from a vegetational viewpoint (e.g. E. palustris-G. declinata communities and E. fluitans-J. heterophyllus communities). In fact, disturbed wetlands present the lower values in plant-community richness in contrast to vernal pools with the higher community richness (Table 3). In terms of soil features, temporary ponds vary from sandy clay loam to loamy sand soils. The $\mathrm{pH}$ values range from moderately (6.3) to strongly (4.4) acidic and $\mathrm{N}$ levels ranged between 0.11 and $0.78 \%$. Mean soil values per habitat showed that marshlands were high in fine particles and that disturbed wetlands were high in $\mathrm{C}$ and $\mathrm{N}$ (Table 3).

Relation between habitat type and environmental variables

The MDA showed that $\%$ clay (Wilks' $\lambda=0.759$ ) and $\mathrm{N}$ content (Wilks' $\lambda=0.740$ ) were the only entered variables (Table 4 ). A total Wilks' $\lambda$ value of $0.457(P<0.001)$ shows the reasonable discriminant power of the model. The discriminant function 1 (DF1) $\left(\lambda_{1}=0.9\right)$ was mainly correlated $(0.688)$ with soil clay, and it explained $85.5 \%$ of total variance, whereas the second discriminant function (DF2) $\left(\lambda_{2}=0.15\right)$ was mainly correlated $(0.364)$ with soil $\mathrm{N}$ content and explained $14.5 \%$ of total variance.

A plot of two canonical discriminant functions (Fig. 3) showed relative good, although unequal, separation of the centroids for the four habitat types. The high discriminant weight of soil clay \% (DF1) was responsible for the segregation between marshlands (negative values) and vernal pool (VP) habitats (positive values). Whereas, DF2 revealed a weak separation of vernal pool and deep pond habitats, DF2 also differentiated disturbed wetlands by soil $\mathrm{N}$ content (positive values).

Discriminant functions appear to have a good classification with $70.4 \%$ of the original cases correctly classified. However, the robustness of this classification resulted from the fitness of only two groups (VP and M). Classification data for each habitat are presented in Table 5. Analysing the cross-validated data, deep ponds' vegetation was the worst-classified group, with $100 \%$ of misclassified cases. 
Table 2 Physiognomy and preferential habitat traits of the 15 community (Comm.) types

\begin{tabular}{|c|c|c|}
\hline Community type & Physiognomy & Habitat \\
\hline A-Agrostis stolonifera Comm. & $\begin{array}{l}\text { Stoloniferous perennial } \\
\text { grasslands }\end{array}$ & Intermediate part in marshlands \\
\hline B-Juncus rugosus Comm. & Rhizomatous rushes & Margins of vernal pools and marshlands \\
\hline $\mathrm{C}$-Juncus capitatus-Isoetes hystrix Comm. & Ephemeral quillwort swards & Margins of vernal pools \\
\hline D_Eleogiton fluitans-Juncus heterophyllus Comm. & Decumbent floating vegetation & Deep part of marshlands and vernal pools \\
\hline $\mathrm{E}$-Eleocharis palustris-Glyceria declinata Comm. & Low helophytic grasslands & Deep part of vernal pools and marshlands \\
\hline $\mathrm{F}$-Juncus emmanuelis Comm. & Rhizomatous rushes & Intermediate part of vernal pools \\
\hline $\mathrm{G}$-Phalaris coerulescens Comm. & Perennial grassland & Disturbed wetlands \\
\hline $\mathrm{H}-$ Agrostis castellana $\mathrm{Comm}$. & Perennial grassland & Margins of vernal pools \\
\hline $\begin{array}{l}\text { I-Eryngium corniculatum-Baldellia ranunculoides } \\
\text { Comm. }\end{array}$ & Swampland thistle forb & Deep part of vernal pools \\
\hline $\mathrm{J}$-Isoetes setaceum Comm. & Ephemeral quillwort swards & Deep part of vernal pools \\
\hline $\mathrm{K}$-Eleocharis multicaulis Comm. & Turf grasslands & Margins of marshlands \\
\hline $\mathrm{L}-$ Ranunculus peltatus Comm. & Ephemeral aquatic crowfeets & $\begin{array}{l}\text { Deep part of the vernal pools and deep } \\
\text { ponds }\end{array}$ \\
\hline M-Chaetopogon fasciculatus Comm. & Annual grasslands & Margins of vernal pools \\
\hline $\mathrm{N}-$ Myriophyllum alterniflorum Comm. & Rooted submerged pondweeds & Deep part of the deep ponds \\
\hline $\mathrm{O}$-Bolboschoenus maritimus Comm. & Bulrushes & Intermediate part of the deep ponds \\
\hline
\end{tabular}

\section{Discussion}

Seasonal Mediterranean wetlands in SW Europe encompass a wide vegetation and community type richness that include both annual and perennial vegetations mainly dominated by grasses and herbs (Deil, 2005). Our study revealed 15 community types floristically distinct for a territory of about $300 \mathrm{~km}^{2}$ in the coastal plain in SW Portugal with a typical Mediterranean climate. These results are similar to those carried out in other Atlantic-Mediterranean areas (Pinto-Gomes et al., 1999; Deil, 2005; EspíritoSanto \& Arsénio, 2005; Bagella et al., 2007). Most of the vegetation corresponded to perennial plant communities $(n=9)$, some annual $(n=4)$, and few are perennating $(n=2)$ (Table 2). The dominance of perennial communities in studied temporary ponds seems to be in contradiction with the established concept that Mediterranean temporary ponds are dominated by annuals (Rhazi et al., 2006; Arguimbau, 2008; Della Bella et al., 2008). In our case study, we found annual plant communities in both ephemeral aquatic habitats mainly at the upper margin. The same pattern of annual vegetation distribution has been documented in other Mediterranean-Atlantic areas (Molina, 2005, Rhazi et al., 2006).
Numerical analysis revealed three main habitats: ponds, marshlands and disturbed wetlands. According to Oertli et al. (2005) in the definition of ponds, the area size of some studied ponds ( $>2 \mathrm{ha}$ ) is oversized, stretching out their segregation from vernal pools (VP) into a 4th group, named deep ponds (L). It is noteworthy that disturbed wetlands (D) result both from the degradation of vernal pools and marshlands (M), by human influence intensification. We infer from these considerations that Mediterranean seasonal wetlands include a variety of habitats not always well classified (Deil, 2005). However, our study shows that plant communities can help to correctly classify habitat types for the case of Mediterranean seasonal wetland ecosystems. Vernal pools showed the greatest diversity in number of community types, and they are definined by hydroseres containing annual grasslands of C. fasciculatus, ephemeral quillwort swards of Isoetes setaceum, and Mediterranean palustrian thistle forbs of E. corniculatum. Deep ponds share with the latter habitats VP vegetation which occurs in their intermediate and marginal belts, but deep ponds also support communities with a longer flooding period such as Myriophyllum alterniflorum and B. maritimus. This fact supports the differentiation of VP and L habitats and vegetation. Marshland habitats have been 
Fig. 2 Principal component analysis plot of habitats in relation to plant communities. $V P$ vernal pool, $M$ marshlands, $L$ deep ponds, $D$ disturbed wetlands. The first principal component explains $46.2 \%$ of total variance and the first two components combined explain $62.2 \%$ of total variance $(n=29)$

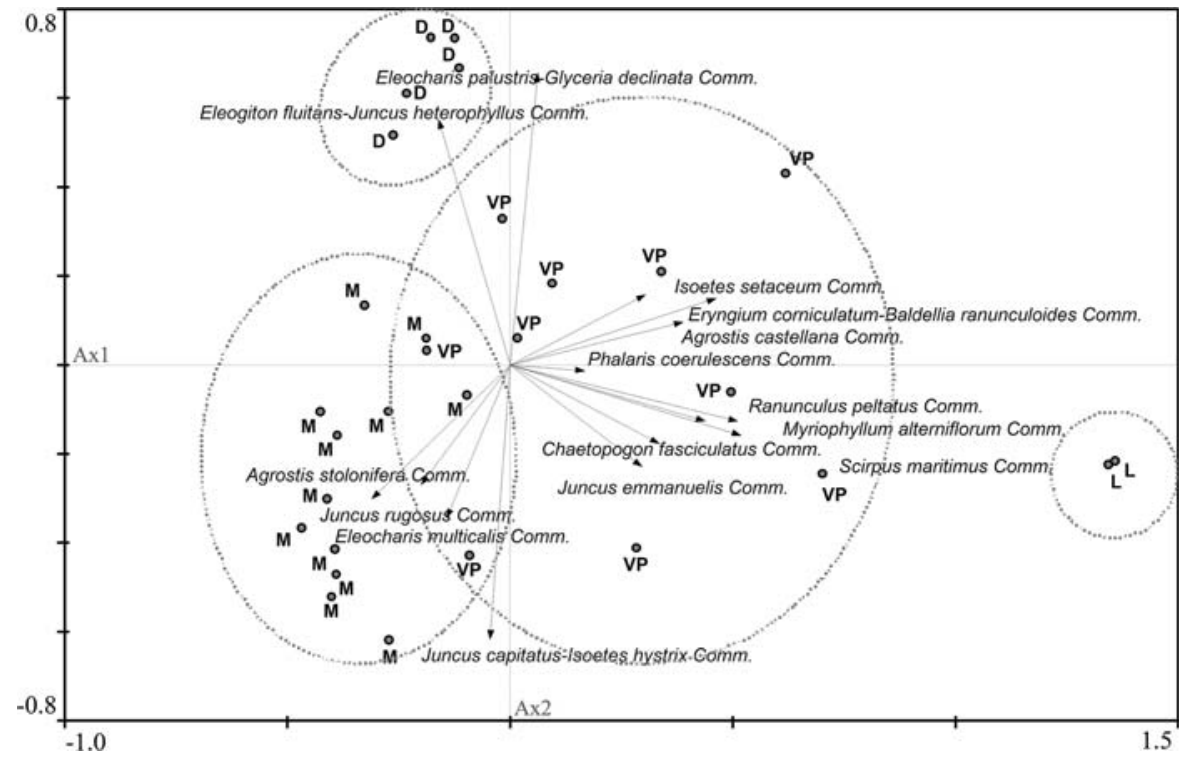

Table 3 Summary of habitats variables

\begin{tabular}{|c|c|c|c|c|c|c|c|c|}
\hline & \multirow{2}{*}{$\begin{array}{l}\text { Species } \\
n\end{array}$} & \multirow{2}{*}{$\begin{array}{l}\text { Communities } \\
n\end{array}$} & \multicolumn{2}{|c|}{ Soil particle size $(\%)$} & \multirow[t]{2}{*}{$\mathrm{pH}$} & \multirow[t]{2}{*}{ Conductivity } & \multirow[t]{2}{*}{ Organic carbon } & \multirow[t]{2}{*}{ Nitrogen } \\
\hline & & & Sand & Clay & & & & \\
\hline VP & 129 & 13 & $61.6(4.62)$ & $20.9(2.62)$ & $5.3(0.06)$ & $156.8(35.43)$ & $1.966(0.299)$ & $0.295(0.030)$ \\
\hline M & 109 & 8 & 83.9 (1.99) & $8.8(1.18)$ & $5.4(0.06)$ & $160.1(25.61)$ & $1.757(0.222)$ & $0.358(0.017)$ \\
\hline $\mathrm{L}$ & 102 & 11 & $64.1(7.65)$ & $20(4.77)$ & $5.6(0.08)$ & $199.2(54.67)$ & $2.269(0.406)$ & $0.265(0.029)$ \\
\hline $\mathrm{D}$ & 63 & 6 & $66(6.33)$ & $21.5(4.04)$ & $5.1(0.14)$ & $357.9(77.37)$ & $2.808(0.4)$ & $0.537(0.053)$ \\
\hline
\end{tabular}

$V P$ vernal pool $(n=34), M$ marshlands $(n=39), L$ deep ponds $(n=8), D$ disturbed wetlands $(n=11)$

Plant species and community diversity, mean values and ranges of physical and chemical variables. The standard error of the mean (SE) is given in brackets

Table 4 Standardized canonical discriminant function coefficients and correlations between discriminating variables and standardized canonical discriminant functions

\begin{tabular}{lcclrl}
\hline & \multicolumn{2}{l}{ Canonical coefficients } & & \multicolumn{2}{l}{ Correlations } \\
\cline { 2 - 3 } & Axis 1 & Axis 2 & & Axis 1 & Axis 2 \\
\hline N content & -1.000 & 0.600 & & -0.471 & $0.882^{*}$ \\
Soil clay (\%) & 1.029 & 0.549 & & 0.514 & $0.858^{*}$ \\
\hline
\end{tabular}

$* P<0.05$

found more closely related to perennial grasslands (Agrostis stolonifera Comm.) and turf vegetation (E. multicaulis Comm.). Disturbed wetlands were related to low helophytic grasslands with the E. palustris-G. declinata community and to decumbent floating vegetation with the E. fluitans-J. heterophyllus community. Both communities play the role of pioneer in the succession dynamics of studied pools.
Although the mean number of taxa per plant community is not very high (Table 1), the total species diversity in studied ecosystems overall is high because of high species turnover from community to community. This fact is supported by the results of similarity analysis, in which all communities are significantly different. This fact can be related to high $\beta$-diversity (Williams et al., 2003; Magurran, 2004). In terms of community richness, the pattern of reduced richness with increasing length of flooding has also been described in different wetland ecosystems (Bauder, 2000; Barbour et al., 2005; Cherry \& Gough, 2006; Edvardsen \& Økland, 2006; Lumbreras et al., 2009). Only a small number of species are adapted to extensive flooding. A consistent explanation to this was provided by Bliss \& Zedler (1998) that studied the effects of different inundation conditions in seed bank germination. According to 
Fig. 3 Plot of the two canonical discriminant functions. $V P$ vernal pool, $M$ marshlands, $L$ deep ponds, $D$ disturbed wetlands

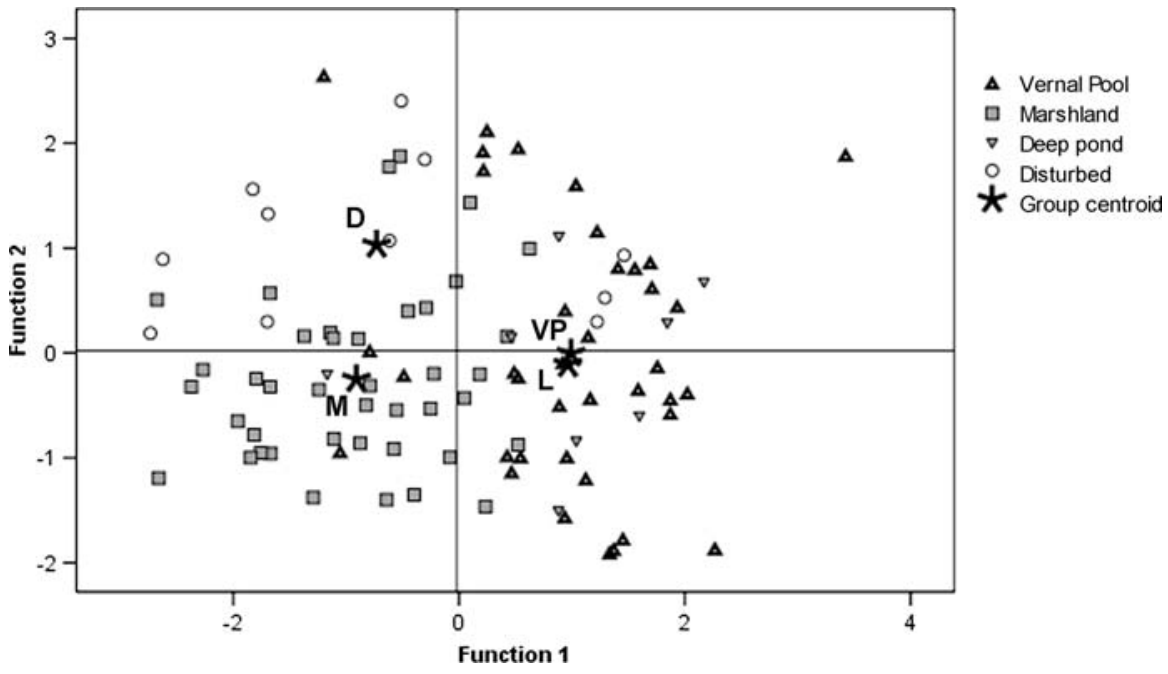

Table 5 MDA classification results

\begin{tabular}{lcccc}
\hline Habitat & \multicolumn{4}{l}{ Predicted group membership } \\
\cline { 2 - 5 } & VP & M & L & D \\
\hline Original (\%) & & & & \\
VP & $\mathbf{8 4 . 2}$ & 7.9 & 0 & 7.9 \\
M & 12.2 & $\mathbf{8 2 . 9}$ & 0 & 4.9 \\
L & 87.5 & 12.5 & $\mathbf{0}$ & 0 \\
D & 27.3 & 45.5 & 0 & $\mathbf{2 7 . 3}$ \\
Cross validated $(\%)$ & & & \\
VP & $\mathbf{8 1 . 6}$ & 7.9 & 0 & 10.5 \\
M & 17.1 & $\mathbf{7 8}$ & 0 & 4.9 \\
L & 87.5 & 12.5 & $\mathbf{0}$ & 0 \\
D & 27.3 & 54.5 & 0 & $\mathbf{1 8 . 2}$ \\
\hline
\end{tabular}

$V P$ vernal pools, $M$ marshlands, $L$ deep ponds, $D$ disturbed wetlands

the same authors the inundation plays a large role in keeping non-pool competitors out of the ponds.

Our results revealed that soil texture and $\mathrm{N}$ content are two soil parameters that are significantly correlated to habitat type. Discriminant analysis provides good classification for vernal pools and marshland, but not for deep pond habitat. These divergent results may be due to insufficient data for deep ponds and disturbed wetlands. Vernal pool and marshland were much more frequently sampled as they appear to be the more abundant habitats. The higher clay $\%$ in vernal pools soil increases their water-holding capacity (Bonner et al., 1997). Nevertheless, in the summer, vernal pools in comparison with marshlands present a more desiccated aspect.

Untested variables not quantified in our study, such as hydroperiod have been shown by others (Rhazi et al., 2001; Grillas et al., 2004; Pyke, 2004; Serrano \& Zunzunegui, 2008; Stamati et al., 2008; Waterkeyn et al., 2008) to be another driving factor. Clearly, more studies on soils profiles and water tables in these ecosystems are required. The intensive land uses like overgrazing or high technology agriculture in the territory can transform vernal pools and marshlands into disturbed ponds edaphically characterised, as shown our results, by a high content in $\mathrm{N}$ as a consequence of cumulative effects in the catchments area (Sileika et al., 2005; Szajdak et al., 2006). The regression of vernal pool habitats, due to anthropic disturbance, affects the abundance of rare communities and species in a specific area; in particular, we can refer to I. setaceum. The change from natural to disturbed wetlands leads to habitat eutrophication as well as a loss in vegetation richness. Moreover, the plant community becomes composed of more wide spread species, diminishing the individualization between described plant communities.

In terms of conservation, it is important to have a good classification of the natural values. Our study demonstrates that both species and plant communities can be used as tools to define wetland habitat typology, as the results clearly show, vernal pool and marshland habitats are strongly separated by floristic attributes. The ponds designated as vernal pools correspond to the Mediterranean temporary 
ponds $\left(3170^{*}\right)$, protected as a priority habitat under the EU Habitats Directive. In our case study, we identified I. setaceum communities and E. corniculatum-B. ranunculoides communities as their characteristic vegetation. Furthermore, submersed Isoetes species (I. setaceum and I. velatum) represents, together with E. corniculatum, the indicator species for vernal pools. I. setaceum is clearly a bioindicator species for Mediterranean temporary ponds. Nevertheless, this species is not included in the Mediterranean temporary ponds definition of the Interpretation Manual of European Union Habitats (EC, 2007). The importance of Isoetes species in this habitat was emphasized earlier by Quézel (1998) and Espírito-Santo \& Arsénio (2005). Conversely, deep ponds have no priority conservation policy, even though they include almost all the communities of vernal pools plus vegetation tolerant of a longer flooded period. Thus, in terms of conservation policy, it is important to take deep ponds into account for the sake of the highly important plant species and communities within them.

The present trend in Mediterranean temporary ponds is clearly regressive, lacking recognition of their value and function which causes them to be readily destroyed or transformed (EC, 2008). In terms of threats, several authors (Zunzunegui et al., 1998; Brinson \& Malvárez, 2002; De Meester et al., 2005; Zacharias et al., 2007) are unanimous in listing changes in drainage and the amount of silting as two of the most important factors that can lead to the loss of these seasonal wetlands. In our study area, the transition from traditional to intensive agriculture, with abandonment of traditional land use practices, represents the major threat. Nevertheless, recently we can observe an increased awareness of the value of temporary ponds, and our results, by identifying habitat indicator plant species and communities, present a helpful tool to establish habitat conservation priorities and strategies.

Acknowledgements The authors are grateful for all the logistical support from the Associação de Beneficiários do Mira. We also like to acknowledge Paula Matono for data analysis suggestions and comments. Special thanks to Rute Caraça for the collaboration in the fieldwork. We would also like to thank the two anonymous referees for the useful and valuable comments.

Open Access This article is distributed under the terms of the Creative Commons Attribution Noncommercial License which permits any noncommercial use, distribution, and reproduction in any medium, provided the original author(s) and source are credited.

\section{References}

ABM (Associação de Beneficiários do Mira), 2007, 2008. Relatório e contas do exercício de 2006 e 2007. Odemira.

Arguimbau, P. F., 2008. Vascular flora associated to Mediterranean temporary ponds on the island of Minorca. Anales del Jardín Botánico de Madrid 65: 393-414.

Bagella S., M. C. Caria, E. Farris \& R. Filigheddu, 2007. Issues related to the classification of mediterranean temporary wet habitats according with the European Union Habitats Directive. Fitosociologia, 44(1).

Barbour, M., A. Solomesch, C. Witham, R. Holland, R. McDonald, S. Cilliers, J. A. Molina, J. Buck \& J. Hillman, 2003. Vernal pool vegetation of California, variation within pools. Madroño 50: 129-146.

Barbour, M. G., A. Solomeshch, R. Holland, C. Witham, R. Macdonald, S. Cilliers, J. A. Molina, J. Buck \& J. Hillman, 2005. Vernal pool vegetation of California: communities of long-inundated deep habitats. Phytocoenologia 35: 177-200.

Bauder, E. T., 2000. Inundation effects on small-scale distributions in San Diego, California vernal pools. Aquatic Ecology 34: 43-61.

Beja, P. \& R. Alcazar, 2003. Conservation of Mediterranean temporary ponds under agricultural intensification: an evaluation using amphibians. Biological Conservation 114: 317-326.

Bliss, S. A. \& P. H. Zedler, 1998. The germination process in vernal pools: sensitivity to environmental conditions and effects on community structure. Oecologia 113: 67-73.

Blondel, J. \& J. Arronson, 1999. Biology and wildlife of the Mediterranean region. Oxford University Press, London: 328.

Bonner, L., W. Diehl \& R. Altig, 1997. Physical, chemical and biological dynamics of five temporary dystrophic forest pools in central Mississippi. Hydrobiologia 353: 77-89.

Braun-Blanquet, J., 1936. Un joyau floristique et phytosociologique «L'Isoetion» méditerranéen. SIGMA Communication 42: 1-23.

Braun-Blanquet, J., 1964. Pflanzensoziologie, 3rd ed. Grundzüge der Vegetationskunde. Springer, Vienna, New York.

Brinson, M. \& A. I. Malvárez, 2002. Temperate freshwater wetlands: types, status, and threats. Environmental Conservation 29: 115-133.

Brullo, S. \& P. Minissale, 1998. Considerazione sintassonomiche sula classe Isoeto-Nanojuncetea. Itinera Geobotánica 11: 263-290.

Castroviejo, S. et al. (eds), 1986-2008. Flora Ibérica, Vols. I, II, III, IV, V, VI, VII (I/II), VIII, X, XIV, XV, XVIII, XXI. Real Jardín Botánico, CSIC, Madrid.

Cherry, J. A. \& L. Gough, 2006. Temporary floating island formation maintains wetland plant species richness: the role of the seed bank. Aquatic Botany 85: 29-36. 
De Meester, L., S. Declerck, R. Stoks, G. Louette, F. De Meutter, T. De Bie, E. Michels \& L. Brendonck, 2005. Ponds and pools as model system in conservation biology, ecology and evolutionary biology. Aquatic Conservation: Marine and Freshwater Ecosystems 15: 715-725.

Deil, U., 2005. A review on habitats, plant traits and vegetation of ephemeral wetlands - a global perspective. Phytocoenologia 35: 533-705.

Della Bella, V., M. Bazzanti, M. G. Dowgiallo \& M. Iberite, 2008. Macrophyte diversity and physico-chemical characteristics of Tyrrhenian coast ponds in central Italy: implications for conservation. Hydrobiologia 597: 85-95.

Dufrêne, M. \& P. Legendre, 1997. Species assemblages and indicator species: the need for a flexible asymmetrical approach. Ecological Monographs 67: 345-366.

EC (European Commission), 2007. The Interpretation Manual of European Union Habitats - EUR27 [online]. European Commission DG Environment, Brussels. Available from: http://ec.europa.eu/environment/nature/legislation/ habitatsdirective/docs/2007_07_im.pdf.

EC (European Commission), 2008. Management of Natura 2000 habitats. *Mediterranean temporary ponds3170. European Commission Technical Report [online]. Available from: http://ec.europa.eu/environment/nature/ natura2000/management/habitats/pdf/3170_Mediterranean_ temporary_ponds.pdf.

Edvardsen, A. \& R. H. Økland, 2006. Variation in plant species richness in and adjacent to 64 ponds in SE Norwegian agricultural landscapes. Aquatic Botany 85: 79-91.

Espírito-Santo, D. \& P. Arsénio, 2005. Influence of land use on the composition of plant communities from seasonal pond ecosystems in the Guadiana Valley Natural Park (Portugal). Phytocoenologia 35(2-3): 267-281.

Franco, J. A., 1984. Nova Flora de Portugal, Vol. II. Edição de Autor, Lisboa.

Franco, J. A. \& M. L. Rocha Afonso, 1994-2003. Nova Flora de Portugal, Vol. III (I-III). Escolar Editora, Lisboa.

Grillas P., P. Gauthier, N. Yavercoski \& C. Perennou, 2004. Mediterranean temporary pools I - issues relating to conservation, functioning and management. Station Biologique de la Tour du Valat, Arles: 120 pp.

INMG (Instituto Nacional de Meteorologia e Geofísica), 1991. O Clima de Portugal. Normais climatológicas da região de "Alentejo e Algarve", correspondentes a 1951-1980. Fasc XLIV, Vol. 4. Lisboa.

ISO/IDF (International Organization for Standardization), 2002. Milk and milk products. Determination of nitrogen content. Routine method using combustion according to the Dumas principle ISO/IDF International Standard (ISO/IDF), No. 14891:2002(E), 185:2002(E), Geneva (Switzerland). International Dairy Federation, Brussels, Belgium.

Jansen, J. \& M. Menezes de Sequeira, 1999. The vegetation of shallow waters and seasonally inundated habitats (Littorelletea and Isoeta-Nanojuncetea) in higher parts of the Serra da Estrela, Portugal. Mitteilungen des Badischen Landesvereins für Naturkunde und Naturschutz 17(2): 449-462.

Keeley J. E. \& P. H. Zedler, 1998. Characterization and global distribution of vernal pools. In C. W. Witham et al. (eds), Ecology, Conservation, and Management of Vernal Pool
Ecosystems. Proceedings from a 1996 Conference. California Native Plant Society, Sacramento, CA: 1-14.

Kent, M. \& P. Coker, 1992. Vegetation Description and Analysis: A Practical Approach. Wiley, England: 363 pp.

Legendre, P. \& L. Legendre, 1998. Numerical Ecology, 2nd ed. Elsevier, Amsterdam.

Lumbreras, A., A. Olives, J. R. Quintana, C. Pardo \& J. A. Molina, 2009. Ecology of aquatic Ranunculus communities under the Mediterranean climate. Aquatic Botany 90: 59-66.

Magurran, A. E. 2004. Measuring Biological Diversity. Blackwell Publishing, 256 pp.

Molina, J. A., 2005. The vegetation of temporary ponds with Isoetes in the Iberian Peninsula. Phytocoenologia 35: 219-230.

Neto, C., J. Capelo, C. Sérgio \& J. C. Costa, 2007. The Adiantetea class on the cliffs of SW Portugal and of the Azores. Phytocoenologia 37(2): 221-237.

Oertli, B., J. Biggs, R. Céréghino, P. Grillas, P. Joly \& J.-B. Lachavanne, 2005. Conservation and monitoring of pond biodiversity: introduction. Aquatic Conservation: Marine and Freshwater Ecosystems 15: 535-540.

Pinto-Gomes, C., A. García Fuentes, A. de Almeida Leite \& P. Cardoso Gonçalves, 1999. Charcos temporários mediterrânicos do Barrocal Algarvio: diversidade e conservação. Quercetea 1: 53-64.

Podani, J., 2001. SYN-TAX 2000. Computer programs for data analysis in ecology and systematics. User's manual. Scientia, Budapest, UH.

Podani, J., 2006. Braun-Blanquet's legacy and data analysis in vegetation science. Journal of Vegetation Science 17: 113-117.

Pyke, C. R., 2004. Simulating vernal pool hydrologic regimes for two locations in California, USA. Ecological Modelling 173: 109-127.

Quézel, P., 1998. La végétation des mares transitoires à Isoetes en région méditerranéenne, intérêt patrimonial et conservation. Ecologia Mediterranea 24(2): 111-117.

Rhazi, L., P. Grillas, A. M. Toure \& L. Tan Ham, 2001. Impact of land use in catchment and human activities on water, sediment and vegetation of Mediterranean temporary pools. C.R. Acad. Sci. Paris Sciences de la vie 324: 165-177.

Rhazi, L., M. Rhazi, P. Grillas \& D. El Khyari, 2006. Richness and structure of plant communities in temporary pools from western Morocco: influence of human activities. Hydrobiologia 570: 197-203.

Rivas-Martínez, S., F. Fernández-González, J. Loidi, M. Lousã \& A. Penas, 2001. Syntaxonomical checklist of vascular plant communities of Spain and Portugal to association level. Itinera Geobotanica 14: 5-341.

Rivas-Martínez, S., T. E. Díaz, F. Fernández-González, J. Izco, J. Loidi, M. Lousã \& A. Penas, 2002a. Vascular plant communities of Spain and Portugal. Addenda to the syntaxonomical checklist of 2001. Itinera Geobotanica 15(1): $5-432$.

Rivas-Martínez, S., T. E. Díaz, F. Fernández-González, J. Izco, J. Loidi, M. Lousã \& A. Penas, 2002b. Vascular plant communities of Spain and Portugal. Addenda to the syntaxonomical checklist of 2001. Itinera Geobotanica 15(2): 433-922. 
Rosselló-Graell, A., D. Draper \& C. Tauleigne Gomes, 2000. Conservation status of mediterranean temporary ponds in Campo Militar de Santa Margarida (Ribatejo, Portugal). Portugaliae Acta Biologica 19: 191-199.

Rudner, M., 2005a. Environmental patterns and plant communities of the ephemeral wetland vegetation in two areas of the Southwestern Iberian Peninsula. Phytocoenologia 35(2-3): 231-266.

Rudner, M., 2005b. Seasonal and interannual dynamics in dwarf rush vegetation in the Southwestern Iberian Peninsula. Phytocoenologia 35(2-3): 403-420.

Serrano, L. \& M. Zunzunegui, 2008. The relevance of preserving temporary ponds during drought: hydrological and vegetation changes over a 16 -year period in the Doñana National Park (south-west Spain). Aquatic Conservation: Marine and Freshwater Ecosystems 18: 261-279.

Sileika, A. S., K. Gaigalis, G. Kutra \& A. Smitiene, 2005. Factors affecting $\mathrm{N}$ and $\mathrm{P}$ losses from small catchments (Lithuania). Environmental Monitoring and Assessment 102: 359-374.

Stamati, F., N. Nikolaidis, E. Dimitriou \& T. Koussouris, 2008. Hydro-geochemical aspects of Mediterranean Temporary Ponds in Western Crete. Journal of Environmental Quality 37: 164-173.

Szajdak, L., I. Yczyñska-Ba£oniak \& M. Szczepañski, 2006. Efficiency of the small pond as a biogeochemical barrier to decrease different kinds of nitrogen in the agricultural landscape. Polish Journal of Soil Science 39: 11-20.

ter Braak, C. J. F \& P. Smilauer, 2002. CANOCO reference manual and user's guide to Canoco for Windows: Software for Canonical Community Ordination (version 4.5). Microcomputer Power, Ithaca, NY, USA.

Waterkeyn, A., P. Grillas, B. Vanschoenwinkel \& L. Brendonck, 2008. Invertebrate community patterns in Mediterranean temporary wetlands along hydroperiod and salinity gradients. Freshwater Biology 53: 1808-1822.

Williams, P., M. Whitfield, J. Biggs, S. Bray, G. Fox, P. Nicolet \& D. A. Sear, 2003. Comparative biodiversity of rivers, streams, ditches and ponds in an agricultural landscape in Southern England. Biological Conservation 115: 329-341.

Zacharias, I., E. Dimitriou, A. Dekker \& E. Dorsman, 2007. Overview of temporary ponds in the Mediterranean region: threats, management and conservation issues. Journal of Environmental Biology 28: 1-9.

Zunzunegui, M., M. C. Diaz Barradas \& F. Garcia Novo, 1998. Vegetation fluctuation in Mediterranean Dune Ponds in relation to rainfall variation and water extraction. Applied Vegetation Science 1: 151-160. 